\title{
eudaimonia
}

Revija za pravnu, političku i

socijalnu teoriju i filozofiju

Br. 3 - 2019.

Izdavač

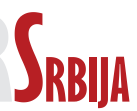

Srpsko udruženje za pravnu

i socijalnu filozofiju

SLOBODA VEROISPOVESTI I POJAM

SEKULARNOSTI U SVETLU EVROPSKE

KONVENCIJE ZA LJUDSKA PRAVA

Vasilije Marković

Strane: $191-220$ 

UDK 342.731

Vasilije Marković*

\section{SLOBODA VEROISPOVESTI I POJAM SEKULARNOSTI U SVETLU EVROPSKE KONVENCIJE ZA LJUDSKA PRAVA}

Ovaj rad pisan je povodom Pete studentske konferencije iz teorije i filozofije prava, pod nazivom - Međunarodno i evropsko pravo, teorijski problemi. Rasprava o značenju termina sekularnosti ima ključni značaj za shvatanje odnosa religije $i$ državnih vlasti, s jedne strane, i pojedinčeve slobode veroispovedanja, $s$ druge strane. Ambijent tog odnosa ključan je za razumevanje ostvarivanja prava iz člana 9 Evropske konvencije o ljudskim pravima $i$ zato je on posebno istaknut $u$ radu, kako s aspekta istorijske geneze, tako i zbog pozitivnog pristupa. Da li sekularnost znači odvojenost države $i$ religije ili u okviru te iste sekularnosti postoje i drugi modaliteti i koji? Gde se u tom pluralitetu odnosa u "postsekularnom" društvu nalazi, a gde treba da se nađe naše društvo? Autor u radu prikazuje sve različitost $i$ evropskih modaliteta $i$ ističe da je neophodno redefinisati pojam sekularnosti $u$ našem društvu budući da je njegova trenutna percipcija potpuno pogrešna. Prvi deo rada bavi se istorijskom genezom procesa $i$ ideja značajnih za razumevanje slobode veroispovesti, drugi je posvećen prikazu različitih modela odnosa Crkve $i$ države, dok treći na primerima prakse Evropskog suda za ljudska prava potvrđuje tezu da su priroda $i$ kvalitet odnosa države i crkve ključni ambijent u kojem pojedinac ostvaruje pravo koje mu garantuju Evropska konvencija i njen član 9.

Ključne reči: Sekularnost. - Laicitet. - Evropska konvencija. - Odnos crkve i države. - Kooperativni model.

\section{OSVAJANJE SLOBODE VEROISPOVESTI - ISTORIJSKI I POZITIVNOPRAVNI AKTI}

Kada su pre nešto više od jednog veka pripadnici tzv. bečkog kruga izneli tezu o skorom kraju religije kao društvenog fenomena ${ }^{1}$,

* Autor je student četvrte godine Pravnog fakulteta Univerziteta u Beogradu,vasilije.markovic227@gmail.com. Zahvaljujem se svom mentoru prof. dr Simi Avramoviću.

1 Z. Krstić, Hrišćanstvo u vrtlozima savremenosti, Požarevac - Kragujevac 2016, 20. 
pre svega oslanjajući se na prosvetiteljsko „skidanje čarolije“ i porast broja libre penseur ${ }^{2}$ na evropskom kontinentu, nisu uzeli u obzir Rankeovu misao da „svet nije mogao podneti da bude pust, napušten od božanstva“. Tome se može dodati još indiktivniji primer, misao prosvetiteljskog velikana Voltera (Voltaire), koji kaže da ako Boga nema, trebalo bi ga izmisliti. I uprkos tome što mi i danas živimo sa posledicama „redukcije vidljive crkve“ - koja je uzrokovala krizu konvencionalne religije i njeno povlačenje od društva, istovremeno s pasivizacijom pojedinaca - prevlast sekularizacije samo je prividna ${ }^{3}$, dok postaje sve jasnije da fenomen religije neće nestati, te se predviđanja pomenutih filozofa ostvaruju jednako kao i ona Fukujamina (F. Fukuyama) predskazanja o kraju svetske istorije. Ta revitalizacija religije i njenog svojstva da kao feniks preživi napade s raznih ideoloških strana ukazuje na to da se na margine gura izolujuća privatnost pod pritiskom sekularizacije kao novog Weltanschauung-a, koji je ništa više do samo još jedna ideologija. ${ }^{4}$ To je bio prvi motiv ovog rada. Drugi motiv za pisanje bio je da se ukaže na izuzetnu važnost garancije prava na slobodno ispoljavanje veroispovesti, bez koje Berđajevljev (Н. А. Берgя́ев) homo religiosus ne bi mogao opstati, uzevši u obzir složen i turbulentan istorijski proces koji joj je prethodio. I najzad, treći i najvažniji motiv bio je da se u habermasovskoj „postsekularnoj“ eri, u kojoj društvo mora računati do daljnjega s opstankom religijskih zajednica, proba da se promeni fokus pod kojim se u našem društvu anahrono sagledava ideal sekularnosti. ${ }^{5}$

Neophodno je, stoga, ukazati na srednji put kojim treba da krene odnos religije, s jedne strane, i države i društva, s druge strane - put obostranog izlaska iz ušančenih položaja ka modernizaciji javne svesti, uz uzajamno razumevanje i neisključivost, kako bi pojedinac pravo

2 P. Dinceblaher, „Religioznost - srednji vek“, Istorija evropskog mentaliteta (ur. P. Dinceblaher), 2009, 143.

3 M. Blagojević, „Savremena religioznost studenata i desekularizacija srpskog društva", Postekularni obrt (ur. M. Blagojević, T. Bajović, J. J. Maksimović), Beograd 2013, 14.

4 I. Alfejev, „Hrišćanstvo pred izazovom militantnog sekularizma“, https://teologija.net/hriscanstvo-pred-izazovom-militantnog-sekularizma, 11. mart 2020.

5 U kojem, za razliku od sekularne ideologije, nema i ne treba da bude ničeg antagonističkog prema religijskom fenomenu. Naprotiv, racionalna sekularnost i hrišćanska religija u „svojoj korelativnoj polifoniji“ treba da budu, kao i do sada, reper evropske civilizacije, međusobno se preispitujući i prožimajući. J. Habermas, J. Racinger, „Dijalektika sekularizacije - iznad uma i religije“, $h t t p s: / / p e s c a n i k / w p$-content/PDF/ Habermas_Racinger_debata.pdf, 11. mart 2020. 
na slobodu veroispovesti, koju mu između ostalih garantuje i član 9 Evropske konvencije, mogao da uživa nesmetano i potpuno. Novo, postsekularno vreme traži novi pristup zasnovan na međusobnom prožimanju na temeljima pluralističkog društva.

Svetonazori su izbačeni iz javnog diskursa, bilo da je reč o ideologiji kojoj religija daje suštinsko obeležje, bilo da je u pitanju njen antipod - sekularna ideologija. Obe su danas, i premoderne i postmoderne $^{6}$, prevaziđene i naterane da krenu jedna drugoj u susret. Taj susret je središnje mesto ovog rada.

Danas pravo svakog čoveka da slobodno i po svojoj savesti misli i veruje i tu svoju veru upražnjava garantuju najznačajniji međunarodni dokumenti, od kojih će nam u fokusu biti posebno Evropska konvencija (EKLJP). Međutim, do sadašnjeg stepena garancije nije se tako lako došlo, već mu je prethodio dug i neretko trnovit put. Neke od najvažnijih prekretnica na tom putu biće posebno spomenute, pre svega zbog toga što smatramo da je istorijska geneza tog prava izuzetno važna, posebno za evropski kontinent.

\subsection{Istorijski osvrt}

Holger Zonabend (H. Sonnabend) navodi da u antici „religioznost nikada nije bila povod za ratove i nasilje, jer je to prirodna posledica shvatanja da su različita božanstva, ništa više do pojavni oblici jednog jedinstvenog božanstvenog načela".7 I zaista, to se potvrđuje na primeru Rimske imperije i njene politike Pax Romana, čiji je pax Deorum bio neizostavan, a možda čak i najvažniji deo. $\mathrm{U}$ tom smislu i Romul - osnivač grada - kao jedan od zadataka kraljeva Rima navodi brigu o žrtvama i ritualima kojima se umiruju bogovi. ${ }^{8}$ Rimske vlasti su tolerisale druge i drugačije kultove pokorenih naroda, ne želeći da krše ravnotežu Pax Deorum-a i intervenišući samo u korist zaštite javnog reda (kao što je bio slučaj s poštovanjima pojedinih božanstava). Rimska kultura je išla korak dalje, ka izvesnom sinkretizmu s istočnjačkim kultovima, smatrajući poštovanje božanstava i učešće u religioznom životu imperativom za pojedinca. Otkud onda predstava da je rimska država bila izuzetno netolerantna prema jednoj maloj judeistič-

\section{Krstić, 127.}

7 H. Zonabend, „Religioznost - Antika“, Istorija evropskog mentaliteta (ur. P. Dincelbaher), Podgorica 2009, 120.

8 Curare sacra ac sacrifica placare Deos. 
koj sekti - hrišćanima, i to počevši od 64 . godine, pa skoro naredna tri veka, u naizmeničnim zatišjima i talasima progona? Postoje dva razloga iz kojih su rimske vlasti vršile verske progone, i to mahom progone hrišćana. Prvi je, kako primećuje Zonabend, političko-socijalni uzrok $i$ privredni razlozi, kao posledica sve lošijeg stanja u državi, koji pogoduju nekim od načela koja su hrišćani zagovarali. Drugi razlog, kao logična posledica prvog, bilo je nerazumevanje hrišćanske zatvorenosti i distance prema društvu, a posebno odbijanje da učestvuju u obredima žrtvoprinošenja i poštovanja zvaničnih, konvencionalnih božanstava bilo onih s Kapitola, bilo raznih „uvezenih“ kultova. Time su hrišćani zadali neoprostiv udarac sistemu Pax Deoruma-a, a samim tim i samoj državnoj politici, što je i bio motiv za progone i označavanje hrišćanske kao nedozvoljene zajednice (collegium illicitum). ${ }^{9}$ Ironija istorije bila je ta da će, odlukom rimskog imperatora Konstantina - jedina religija koja nije našla svoje mesto u rimskom religijskom sistemu - taj, ionako urušeni sistem, potpuno uzdrmati i zameniti, dajući nov izgled Rimskoj imperiji. Kamen temeljac tog procesa, ali ne samo njega već $\mathrm{i}$ verske tolerancije i naše današnje kulture uopšte, bio je Milanski edikt objavljen 313. godine, koji je doneo imperator Konstantin, koji se na to odvažio usled mešavine ličnih, religioznih, političkih i privrednih motiva. Tim aktom se verska sloboda nije garantovala samo hrišćanima, već i svim drugim religijama. Međutim, religija koju je država u jednom trenutku zabranjivala sada je poput kakvog trojanskog konja uspela da, oslanjajući se na starorimsku tradiciju jedinstva države i religije, u daljem razvoju carstva poništi princip ravnopravnosti religija koji je jemčen Milanskim ediktom. Naime, Konstantinova ideja o jednakosti svih religija nije mogla da se održi pred tradicijom državnog kulta, te je ranije mnogobožačke bogove, na mestu državne religije, sada smenila hrišćanska religija. Zato, kako navodi prof. Miljković, kasniji zakoni nisu sledili duh Milanskog edikta ${ }^{10}$, te su ustoličili sistem koji je kasnije bio poznat kao cezaropapizam (ili, obratno, papocezarizam) ili vizantijska simfonija države i crkve.

Kohezivan, politički potencijal religije uviđali su posle Konstantina i ostali vladari srednjeg veka, tokom kojeg je religija imala ulogu učvršćivanja kolektivnog karaktera. Ovde želimo da naglasimo da se važnost ovakvog istorijskog osvrta upravo vidi u prelamajućim tač-

9 D. Mitrović, „Troicki o mestu Crkvenog prava i njegovom odnosu s državnim pravom“, Pravo, vera i kultura (ur. A. Raković, V. Đurić), Beograd 2012, 74.

10 D. Perić, Crkveno pravo, Beograd 2006, 180. 
kama, budući da sloboda veroispovedanja, kako se primećuje u radu, direktno zavisi od konkretnog ambijenta i odnosa između religije i društveno-političke zajednice u kojoj pojedinac tu slobodu ostvaruje. Sledeći momenat koji je, posle Edikta iz 313. godine, trebalo osvojiti u borbi da se ta sloboda prizna pojedincu jesu verske krize i sukobi u Evropi od pojave protestantizma, preko Augzburga do vestfalijanskog mira. Ovde se dešava rascep između sprega koje postoje u državnoreligijskom odnosu, iz kojih izviruje pojedinac sa svojim zahtevima za slobodom, koja podrazumeva i slobodu propovedanja i ispovedanja vere koju smatra istinskom i svojom.

Individualizujući takvu slobodu i smatrajući da država nema razlog da zadire u nju, Lok (J. Locke) u Pismima o toleranciji kaže da je država „zajednica ljudi konstituisana samo zbog postizanja očuvanja i unapređenja njihovih sopstvenih građanskh interesa (...) i da briga za dušu nije dužnost građanskog vladara više no drugih ljudi“. Na drugom mestu u pismu on ističe:

Vladar kao i svaki drugi pojedinac, ima pravo da ubeđuje, a nikako da naređuje podanicima da pređu u njegovu veru. Ova vlast ne može da se dodeli vladaru pristankom naroda pošto nijedan čovek ne može u toj meri da napusti brigu za svoj spas i izbor prepusti nekome drugome - vladaru ili podaniku koji bi mu pomogao koje bogoslouženje da prigrli. Jer nijedan čovek, čak i kad bi to hteo, ne može svoju veru da uskladi prema naredbi drugoga. Ceo se život i moć istinske religije nalazi u unutrašnjem i potpunom pridobijanju duha a vera nije vera ukoliko u nju ne veruje. ${ }^{11}$

Isti argument sa gotovo identičnom terminologijom nalazimo kod ranohrišćanskog apologete Tertulijana (Q. S. F. Tertullinianus, 3. vek n. e.), u njegovoj poslanici konzulu Skapuli (Ab Scapulam). Zanimljiva je činjenica da Tertulijan, više od deset vekova pre Loka, iznosi pomenutu lokovsku tvrdnju da nije deo religije da aktom prisile preobraćuje pripadnike drugih religija, dodajući još ponešto o lojalnosti hrišćana državnim vlastima i razvrgavanju stava da hrišćanska zajednica treba da ostane nedozvoljena u rimskom sistemu.

Lok pak u svom delu, osim toga što koristi religiozne tekstove (nije isključeno da mu je inspiracija bila upravo ovaj Tertulijanov spis), pokazujući njihovo izuzetno poznavanje, uspostavlja toleranciju kao načelo bez kojeg ni država ni religija ne mogu opstati. Ovo stoga što

11 Dž. Lok, Pismo o toleranciji, Beograd 2015, 36. 
za njega, kao člana tzv. hrišćana platonista, jednakost ima najtvrđi autoritet kao jedan od teoloških aksioma. ${ }^{12}$ Lok dakle stoji na stanovištu da sveto nije protivnik, ali sa ciljem jednakosti i individualizacije slobo$d e^{13}$ naglašava važnost razdvajanja crkve i države, kako bi država mogla ostati nepristrasna u tim stvarima i kako bi se mogla starati o jednakosti svih pred zakonom. ${ }^{14} \mathrm{U}$ zaključku svog dela Lok poručuje da bit svega onoga čemu stremimo jeste da svaki čovek uživa ista prava koja su data.

Upravo na takvom stremljenju gradi se liberalnodemokratsko društvo i društvo pluralističke tradicije, u kojem se religija sve više potiskuje u privatnu sferu, pri čemu joj se zaštita daje isključivo u tom domenu (a ne, kao ranije, zbog njenog kolektivnog značaja). I tako dolazimo do poslednje, opet krizne, ali ključnih tačaka u istorijskom razvoju slobode veroispovesti, a to su Deklaracija o pravima čoveka i gradanina i Francuska buržoaska revolucija. U samom duhu Deklaracije može se primetiti borba između čistog Lokovog liberalizma (posebno član 4) ${ }^{15}$ i političke filozofije Rusoa, koji naglašava uticaj države čak i $\mathrm{u}$ iracionalnim elementima, poput ljubavi prema Bogu, budući da sam ratio u prihvatanju društvenog ugovora u izgradnji političke zajednice nije dovoljan. Tako Ruso promoviše koncept tzv. građanske religije, koju čak država treba da nametne svim građanima Republike i, na neki način, ona je iracionalna senka racionalnog, političkog delovanja društvenog ugovora. Ruso tako ne dozvoljava u principu nikakvu drugu dogmu koja bi mogla dovesti građanske dužnosti u pitanje (nalik nekadašnjoj rimskoj imperiji). ${ }^{16}$ Ovde se može govoriti o vođenoj slobodi savesti, koja sa istinskim liberalizmom koji se pominje u Lokovim delima nema veze, ali čiji će produkt biti jaka nacionalna crkva Francuske u periodu neposredno posle revolucije.

Sama sloboda veroispovesti u tekstu Deklaracije regulisana je članom 10, koji je bio predmet žestokih sporenja. Nakon što je prošao sve

12 R. Trigg, „Religion in the Public Forum“, Ecclesiastical Law Society 2011, 275; J. Waldron, God, Locke and Equality: Christian Foundations in Locke's Political Thought, Cambridge 2002, 11.

13 M. Božić, Laička država kao jemstvo slobode savesti i veroispovesti, Beograd 2010, 92.

$14 \mathrm{Na}$ talasu individualizma i slobode da se po savesti biraju uverenja, Lok, posle perioda verskih sukoba, kojima je bio lično užasnut, i s teološke strane osporava legitimitet verske netolerancije i nametanja uverenja državnom ili oružanom silom „iskrena vera ne može se nametnuti“. Takođe, treba napomenuti da se granice Lokove tolerancije iscrpljuju, a da izvan nje ostaju pojedine grupe, na primer ateisti.

15 Božić, 138.

16 Ibid., 124. 
redakcije republikanskog „toplog zeca“, njegova usvojena verzija glasi: "Niko ne može biti uznemiravan zbog svog uverenja, pa i religijskog.“ Posle ovako šturo i negativno definisane slobode veroispovesti dolazi član koji govori o slobodi izražavanja, tj. slobodi štampe. Taj član (11) kritikovan je s više pozicija. Pojedini su (poput Virijea) smatrali da slobodu veroispovesti uopšte ne treba tretirati zajedno sa slobodom mišljenja. Republikanci su zagovarali ograničenje u vidu poštovanja zvaničnog kulta, a konačnu liberalnu prevagu odneli su Mirabo (H. G. $R$. de Mirabeau) i Sent Etjen, koji su oštro kritikovali koncept tolerancije, nazivajući je idejom sažaljenja, tiranskom i suprostavljajući joj superiorni koncept neograničene religijske slobode kao svetog prava, jednog za sve. ${ }^{17}$ Ipak, baš kao i ranije pominjana rimska država, ni Francuska nije ostala dosledna liberalnim proklamacijama Deklaracije već je donošenjem Građanskog ustava o kleru izneverila njene liberalne ideale. Iako se i dalje zalaže za religioznost kao deo isključivo privatne sfere pojedinca, taj akt podređuje crkvu državi i čini jednu neobičnu tvorevinu nacionalne crkve, atipičnu za ostatak katoličkog sveta. Opravdanje za takav ideološki non-sense je višestruk: površnost pisaca akta, koji su ga iz liberalne protestanske sredine uvrstili u, za to nepogodno, francusko društvo; zatim, Rusoova republikanska filozofija i želja da se, možda i iz nepoverenja prema nekadašnjem drugom staležu, on drži blizu i kontroliše i da bude podređen državi (umesto potpuno odvojen) i u sferi van državnog delovanja, kao što liberalni ideali nalažu. Kako bilo, i ta nam epizoda još jednom pokazuje koliko je ravnoteža između države i religije bitna kako bi se prava pojedinca mogla potpuno ostvariti. Iako je možda u procesu i bilo nekih skretanja prema afirmaciji prava pojedinca (o čemu će još biti reči), Francuska revolucija i Deklaracija su imale veliki značaj za razvoj ideja jednakosti koje su, na kraju krajeva, dovele do sadašnjih, pozitivnopravnih rešenja tog pitanja, koja svoju inspiraciju i ideološku pozadinu upravo vide u Revoluciji.

\subsection{Pozitivni akti}

Svako ima pravo na slobodu misli, savesti i veroispovesti; ovo pravo uključuje slobodu promene veroispovesti ili uverenja i slobodu da čovek sam ili u zajednici s drugima javno ili privatno manifestuje svoju veru ili uverenje podučavanjem običajima molitvom i obredima (čl. 18 Univerzalne deklaracije o ljudskim pravima).

17 Ibid., 141. 
Najznačajniji pozitivni akti iz oblasti ljudskih prava, poput Univerzalne deklaracije o ljudskim pravima (1948), završnog akta Helsinške konferencije iz 1975, Pakta o građanskim i političkim pravima (PGPP) i Pakta o ekonomskim, socijalnim i kulturnim pravima (PESKP), čvrsto se oslanjaju na racionalističke teorije i jak individualizam koji je, kao što smo videli, izražen od 1789. godine. Ličnosni karakter ljudskih prava, koji se oslanja na hrišćansku antropologiju, zamenjen je racionalističkim antropocentrizmom i individualizacijom. ${ }^{18} \mathrm{Ne}$ ulazeći dublje u dijalektički odnos ličnost-individua, o kojem Vlasije Fidas ( $V$. Fidas) detaljno piše i koji obeležava pozitivne akte iz oblasti ljudskih prava, zadržaćemo se samo na uticaju koju je ta promena imala na slobodu misli, savesti i veroispovesti jer, kao što piše Racinger ( $J$. A. Ratzinger), tamo "gde bog više nije summum bonum, njegov položaj se menja čak i za pojedinca“. To je potvrdio izveštaj iz 2007. o interkulturalnom i religijskom dijalogu, u kojem se od država traži da od religijskih lidera zahtevaju (?!) da „nedvosmisleno pretpostave bilo koji religijski princip konceptu ljudskih prava onako kako su postavljene u Konvenciji“. ${ }^{19}$ Takav problematičan zaključak može se razumeti ako se religija shvati kao preteća sila ${ }^{20}$, ali ako se usvoji, na kraju će osiromašiti koncept ljudskih prava i ostaviti ih bez jednog od valjanih utemeljenja.

Kako se, dakle, Deklaracijom i paktovima ljudskih prava reguliše sloboda veroispovesti?

Sloboda mišljenja, savesti i verospovesti, kao svojevrstan lex generalis u odnosu na slobodu izražavanja mišljenja (baš kao i u revolucionarnoj Deklaraciji), regulisana je članom 18 Univerzalne deklaracije o ljudskim pravima, kao i članovima 18 PGPP $i 9$ EKLJP. Paktom se mnogo detaljnije reguliše to ljudsko pravo, time što se uvodi poznati negativni aspekt da se niko ne može podvrgnuti prinudi koja bi naštetila slobodi ostajanja ili izbora nove religije. Takođe, u PGPP su predviđena i klasična fakultativna ograničenja tog prava u slučaju kada je to zakonom propisano i neophodno u demokratskom društvu radi zaštite opšteg interesa. Ipak, ni u jednoj od tih odredaba nije bliže određeno šta se sve podrazumeva pod verom, a izostala su i još

18 V. Fidas, Kanoni i dijalog, Beograd 2018, 257.

19 State, Religion, Secularity and Human Rights, Report to the Parliamentary Assembly of the Council of Europe, https://assembly.coe.int/nw/xml/XRef/X2H-XrefViewHTML.asp?FileID=11607\&lang=EN, 11. mart 2020.

20 Trigg, 276. 
neka razjašnjenja određenih pojmova. Stoga je dragoceno tumačenje Komiteta za ljudska prava Ujedinjenih nacija, koji je kao ugovorno telo ovlašćen da tumači opštim komentarima nedovoljno razrađene i definisane odredbe PGPP-a. Tako je u Opštem komentaru broj 22 pojam vere proširen na sve vrste teističkih, neteističkih, ali i ateističkih uverenja. ${ }^{21}$ Takođe, osim pojma vere, u Komentaru su bliže određene i definicije molitve i obreda, uključujući i aktivnosti poput: upotrebe ritualnih formula i objekta, isticanje simbola, poštovanje praznika i potpuni liturgijski život. ${ }^{22}$

Svi pomenuti akti garantuju upražnjavanje prava na slobodu veroispovesti samostalno ili zajedno s drugim licima, čime se naglašava dualni karakter tog prava - kao pojedinačnog i kao prava zajednice. Obe komponente, i indivudalna i zajednička, moraju se zadovoljiti, ali dalje od toga Deklaracija i PGPP nisu išli u određivanju sadržine tog prava. Zato je 1981. godine doneta, doduše pravno neobavezujuća, Deklaracija o eliminaciji svih oblika diskriminacije zasnovane na netoleranciji ili uverenju, koja je neisključujućom enumeracijom u članu 6 utvrdila sadržinu prava na slobodu veroispovesti. Tako se pod njom podrazumevaju i: izdavanje publikacije iz religijskih oblasti, osnivanje humanitarnih organizacija, obuka i imenovanje lidera, proslava praznika i ceremonija, uspostavljanje i održavanje komunikacije u vezi sa religijom sa pojedincima i zajednicama na nacionalnom i internacionalnom nivou. ${ }^{23} \mathrm{U}$ skladu sa time, Deklaracija pomaže u sprovođenju i zaštiti slobode veroispovesti koja je, pomalo šturo, definisana u Univerzalnoj deklaraciji i PGPP-u.

To bi u najkraćem bio osvrt na način na koji je u sistemu Ujedinjenih nacija regulisano pitanje prava na slobodu veroispovesti, dok će o rešenju tog pitanja u sistemu Evropske konvencije (1950) više biti reči na posebnom mestu.

Što se tiče Evropske unije, kao najmlađeg i najužeg regionalnog sistema zaštite na našem kontinentu, zaštita i poštovanje verskih i filozofskih sloboda jesu naznačeni i u primarnom i u sekundarnom zakonodavstvu EU. Osnovni akt primarnog zakonodavstva je svakako lisabonski „ustav" Unije, simbolično poptisan ispred statue poglavara Katoličke crkve, čime se hteo dati omaž hrišćanskom kohezivnom fak-

21 I. Krstić, M. Paunović, B. Krivokapić, Međunarodna ljudska prava, Beograd 2016, 195.

22 Ibid., 196. 
toru evropskog identiteta, koji je našao svoje mesto i u preambuli Lisabonskog ugovora. Osim toga što priznaje relevantne odredbe Povelje osnovnih sloboda i EKLJP, u članu 52 Lisabonskog ugovora posebno se uređuje status verskih zajednica i kaže se da Unija ne prejudicira položaj verskih zajednica po nacionalnim pravima i da jednako poštuje status filozofskih i nekonfesionalnih organizacija. ${ }^{24}$ Ta prva dva stava proistekla su iz završnog akta Deklaracije Amsterdamskog sporazuma, koja je usvajanjem Lisabonskog sporazuma nedvosmisleno postala pravno obavezujući dokument. Stav 3 člana 52 je posebno zanimljiv i u njemu se, uz poštovanje identiteta crkava i verskih zajednica, EU podstiče na transparentan i redovan dijalog sa njima. Time se pokazuje jedan proaktivan pristup Evropske unije, koja priznaje doprinos crkava i verskih zajednica identitetu Evrope i usmerava svoje organe na aktivnu saradnju sa njima u pitanjima od obostranog interesa. Smisao tog stava jeste i u tome što treba da prizna posebnost crkve i verske zajednice u odnosu na druge ustanove građanskog društva, sa kojima je takođe naložen dijalog, ali drugim članom. Od sekundarnih izvora komunitarnog prava posebno su značajne Direktive o televiziji $i$ jednakom tretmanu zapošljavanja. Što se tiče ograničenja verskih prava garantovanih Ugovorom, propisano je da ta ograničenja moraju biti u skladu sa članom 9, stav 2 EKLJP, o kojoj će još biti reči.

\section{SEKULARNOST I LAICITET: DVE STRANE JEDNE MEDALJE?}

Između pojmova sekularnosti i laiciteta sve češće se povlači znak jednakosti, čak i u nelaičkim krugovima, a tanane razlike koje između ta dva pojma postoje isuviše se lako zapostavljaju. ${ }^{25}$ Osnov za olako poistovećivanje dao je Šampion, karakterišući ih kao dva stabla koja niču iz istog korena, a taj koren je razdvajanje crkve i države. Dakle, i sekularnost i laicitet su dve strane iste medalje i obe služe istom cilju razdvajanju političkog i religijskog. ${ }^{26}$ I pored toga, u daljoj analizi iskrsavaju razlike koje udaljuju ta dva pojma, koja se razlikuju po mnogo

24 G. Robers, „Država i crkva u EU“, Država i crkva u Evropskoj uniji (ur. G. Robers), Beograd 2012, 14.

25 S. Avramović, „Poimanje sekularnosti u Srbiji - refleksije sa javne rasprave u Ustavnom sudu“, Anali Pravnog fakulteta u Beogradu 2/2011, 294.

26 Božić, 2. 
čemu, izuzev po svome krajnjem cilju. Tako je za laicizaciju naročito karakteristična oštrina i radikalizacija sukoba s crkvom na racionalističkoj kritičkoj osnovi koja se javila mahom u katoličkom delu Evrope, a njen najistaknutiji primer nalazimo u slučaju Francuske. S druge strane, proces sekularizacije uglavnom pripada tradicionalnim protestantskim sredinama i zemljama u kojima nije bilo izraženijeg sukoba države i crkve već je, naprotiv, postojala saradnja u mnogim oblastima u stvaranju liberalnog društva. Tako su s istim polaznim ciljem i iz dve različite tradicije proizašla dva potpuno različita sistema - sekularni u SAD i laički u Francuskoj. Dok prvi karakteriše podsticanje negovanja ličnih uverenja u pravnim okvirima, čiji je establishment clause značajan deo, drugi karakteriše stroga kontrola izražavanja verskih ubeđenja u javnom prostoru. I samo značenje laiciteta u modernom svetu žudi za redefinisanjem, budući da od borbenog antiklerikalnog naboja nije ostalo ništa ni u samoj njenoj kolevci - Francuskoj, a pojam sekularnosti $^{27}$ je toliko širok da pokriva raznovrstan dijapazon rešenja kojima su uređeni odnosi države i crkve. Iz svega toga proizilazi da sekularnost i laicitet ipak ne treba tretirati kao sinonime.

\subsection{Francuska, Sjedinjenje Američke Države i ostali modaliteti uređenja odnosa države i crkve}

Primer Francuske je iz više razloga zahvalan za analizu. Najpre, to je prva država u kojoj se proces desakralizacije pojavio nošen liberalnodemokratskim duhom Revolucije iz 1789. godine. U liberalnodemokratskoj ustavnoj kulturi, proces razdvajanja crkve i države treba da služi garanciji slobode savesti. Međutim, u prvim godinama posle revolucije, jakobinski talas i njegov jaki antiklerikalni sentiment dali su obeležje pojmu laiciteta i borbi Francuske Republike protiv katoličke crkve. U otvorenoj i oštroj antihrišćanskoj i anticrkvenoj delatnosti posebno su se istakli hebertisti sa svojim, ponekad nasilnim, merama protiv klera, a zatim je sledio pokušaj podmetanja građanske religije - religije odanosti Republici umesto Bogu. Potrebu za tom novom specifičnom religijom umesto stare, protiv koje se treba boriti ili je barem pokoriti pod vlast Republike, objasnio je Vašero u knjizi O pravdi u revoluciji i Crkvi, pišući da crkvene dogme ne mogu pripremiti čoveka za self-government, to jest ne mogu stvoriti građanina kao potrebu novog

27 Treba ga razlikovati ga od termina sekularizma, kojim se označava jedna agresivna ideologija koja se samo nominalno poistovećuje s načelom sekularnosti. 
vremena. ${ }^{28}$ Zato će - posle kratkotrajnih perioda reklerikalizacije francuskog društva za vreme restauracije i Julske monarhije - od stabilizovanja Treće republike ponovo započeti proces konačnog razdvajanja crkve i države. Najznačajniji korak na tom putu jeste Zakon o separaciji iz 1905. godine, čija je antiklerikalna suština izražena u članu 2, kojim se predviđa da Republika ne priznaje, ne izdržava niti subvencioniše verske zajednice. Pa ipak, vredno je spomenuti da nastavak tog člana uopšte nema sličan antiklerikalni prizvuk, budući da predviđa izuzetak u više delatnosti, poput kapelanskih službi u državnim institutima zatvorenog tipa, u bolnicama i internatima. S tim izuzetkom, takav razlaz države i crkve više nalikuje neutralnom odnosu države prema crkvi nego antiklerikalnoj meri. I aktuelni Ustav Pete Republike se u preambuli poziva na Deklaraciju iz 1789, negujući tradiciju zakona iz 1905. godine i promovišući državnu neutralnost kao način jednake garancije slobode veroispovesti. ${ }^{29}$ Tako državna neutralnost, a ne antiklerikalni karakter, postaje ključna osobina francuskog laiciteta. Francuska zaslužuje poseban osvrt zbog toga što je bila pionir i udarna pesnica separacije. Drugi razlog je moderni trend koji dobija sve veći zamah u pravnoj teoriji, ali i praksi Pete Republike. To je svojevrsno zatvaranje kruga odnosa države i crkve, to jest koncept otvorenog laiciteta. To više nije negativna neutralnost države prema religijskim zajednicama već se, u skladu s tendencijama koje opisujemo u ovom radu, i francuska država okreće i izlazi u susret verskim zajednicama. Ta sada pozitivna neutralnost uključuje religijsku raznovrsnost $i$ dozvoljava saradnju religijskih i državnih institucija kada ta saradnja poštuje njihovo polje delovanja $i$ autonomiju. ${ }^{30}$ Argument u prilog tom konceptu je prošireni član 1 Ustava iz 1958. godine, u kojem se kaže da Republika poštuje sva verovanja, a svoj praktični izraz taj sve prihvaćeniji model otvorenog laiciteta ima u primerima sastajanja biskupa Francuske na mesečnom nivou s zvaničnicima vlade ${ }^{31}$ ili službe za verska pitanja Ministarstva unutrašnjih poslova, koja postoji još od vremena De Gola. Time je prikazana celokupna evolucija pojma laicitet - od njegovog izvorišta do današnjeg, umnogome, redefinisanog značenja i primene.

Kao što se za Francusku vezuje termin laiciteta, tako se za Sjedinjenje Američke Države vezuje prototip sekularne države. Naslonje-

28 Božić, 191.

29 Neutralnost države se i tumači kao doborovoljno ograničavanje nadležnosti metafizičkog verovanja koja se prepušta indivudalnim savestima (ibid., 230).

30 Ibid., 238.

31 Avramović, 295. 
na na individualističku postavku, ustavna tradicija SAD lišava religiju svakog uticaja na državne poslove, ali i obrnuto. Kao posledica, u SAD je potpuno izostala državna regulativa priznanja, registracije, ali i finansiranja verskih zajednica, pri čemu se istovremeno zabranjuje da se bilo koja religija nađe u privilegovanom ili u položaju zvanične religije (tzv. establishment clause). Ipak, budući da su SAD sekularna država ali religiozno društvo ${ }^{32}$, ni ovde ne možemo govoriti o nekakvim hermetički razdvojenim prostorima, paralelnim sredinama u kojima se pojedinci ostvaruju - u jednom kao građani sekularne države, u drugom kao vernici - naprotiv. Blizak dodir javnog prostora i religije u SAD, koji na neki način predstavlja izuzetak od prvog amandmana, vidljiv je u brojnim primerima. ${ }^{33} \mathrm{Da}$ bi ti i drugi primeri odstupanja od striktne primene prvog amandmana bili validni pred Vrhovnim sudom, oni moraju proći trodelni test - da je reč o opšteprihvaćenom postupku u društvu, koji je simboličkog karaktera i koji je neutralnog religijskog karaktera, to jest upućuje na opšteprihvaćeno mesto univerzalne religiozne ideje, a ne na neku konkretnu dogmu ili denominaciju. ${ }^{34}$ To je samo još jedan pokazatelj da sekularnost, čak i tamo gde je najdoslednije sprovedena, ne može hirurški da odvoji religijsku komponentu od društvenog života jer je, kako piše Habermas:

...svetonazorska neutralnost države koja svakom građaninu jemči jednake slobode nespojiva s političkim uopštavanjem sekularnog pogleda na svet. Sekularizirani građani, ukoliko nastupaju u ulozi građana države, ne smeju načelno ni religijskim slikama svijeta osporiti potencijal istine niti sugrađanima, vernicima oduzeti pravo da religijskim jezikom daju svoj doprinos javnim raspravama. ${ }^{35}$

U suprotnom, može se lako skliznuti u diskriminaciju, a zabrana diskriminacije ponekad ima i prvenstvo u odnosu na prvi amandman. ${ }^{36} \mathrm{U}$ suprotnom, to bi značilo formalnu i slepu jednakost koja, kao što znamo, vodi u antipod pravde. Dakle, sama suština sekularno-

32 Božić, 77.

33 Kao samo neki primeri, u literaturi se navode natpis In God We Trust na novčanici, zakletve na Bibliji i redovne molitve u Kongresu pre početka zasedanja.

34 Božić, 78.

35 „Dijalektika sekularizacije - iznad uma i religije“, https://pescanik.net/wpcontent/PDF/Habermas_Racinger_debata.pdf, 11. mart 2020.

36 Kao u slučaju Good News Club v. Milford Central School, u kojem je, prema presudi, škola diskriminatorski postupala i protežirala sekularni oblik ponašanja nad religijskim, na koji su učenici imali potpuno pravo. 
sti, a SAD su najbolji primer za to, nije da onemogući religijsku praksu u javnom prostoru već da je učini mogućom u skladu s verskim i vrednosnim pluralizmom, držeći se pritom neutralnosti, ali ne i indiferentnosti države. ${ }^{37}$

Osim Francuske - kao začetnika razdvajanja svetog i svetovnog i primera laičke države, i SAD, kao najindikativnijeg primera sekularne države - pluralizam ustavnih rešenja i tradicija iznedrio je i ostale tipove i podtipove odnosa religije i države. Prema podeli koju navodi Avramović, na jednom polu se nalazi sistem tzv. državnih crkava (poput Engleske ili Grčke), koji trpi određene modifikacije i relativizaci$\mathrm{ju}^{38}$, a na drugom polu je izloženi sistem striktne odvojenosti, u kojem je nekad prednjačila Francuska, ali i taj sistem, trpeći modifikacije, gravitira ka sredini. To srednje rešenje je sistem odvojenosti, ali ne potpune već kooperativne, u kojoj država i crkva sarađuju na svim bitnim zajedničkim poljima ${ }^{39}$, što postaje ključni pojam u okvirima EU, a posle pada komunizma i u celoj Evropi, kako navodi S. Ferari u svom radu za časopis Fides et Libertas. Malo drugačiju, detaljniju, ali suštinski identičnu lepezu tipova uređenja odnosa religije i države, u okviru koje se ostvaruje i forum internum i forum externum prava na slobodu veroispovesti, nudi Marko Božić u svojoj disertaciji. U njegovoj podeli nailazimo na sisteme nacionalnih crkava, utemeljenih crkava, priznatih crkava i sekularne države (SAD). Kao tipična predstavnica skandinavskog tipa nacionalnih crkava (od kojih je jedino Švedska izuzeta zakonom iz 2000. godine i odvojena od države) navodi se danska folkiirk ${ }^{40}$ - narodna crkva. Ona je Ustavom proglašena nacionalnom crkvom i, sledstveno tome, uživa državnu zaštitu. Sličan primer nailazimo južnije, u Grčkoj, koja zbog svoje pravoslavne dominantne religije, ali i aktuelne situacije, nama može biti još zanimljiviji slučaj. U preambuli njenog Ustava istaknut je značajan religijski prizvuk (proglašen je $u$ ime nedeljive Trojice $)^{41}$, a pravoslavlje je proglašeno dominantnom religijom, što ima brojne posledice - na primer, polaganje zakletve pred Sinodom. ${ }^{42}$ Još važnija osobenost Grčke je kriminalizacija napadnog

37 Božić, 79.

38 Svedoci smo jedne od takvih modifikacija u Grčkoj, koja se prepoznaje u namerama Vlade da redefiniše status Atinske arhiepiskopije.

39 Avramović, 282.

40 Božić, 29.

41 Ibid.

42 Što je izostalo u jednom od poslednjih saziva grčkog parlamenta zbog ideoloških stavova vladajuće partije. 
i organizovanog prozelitizma, posebno ograničenje slobode savesti, koje je Grčku izložilo mnogim kritikama i dalo joj je zapaženo mesto u učestalosti predstavki u arhivama Suda u Strazburu povodom kršenja prava iz člana 9 EKLJP. Kao predstavnici sistema priznatih crkava-sistema, koji se nalaze između sistema državnih crkava i sekularnog društva, navedene su Nemačka, Italija i Holandija, opet svaka sa svojim specifičnostima. Nemačka specifičnost je $u$ tome što se nalazi tačno na sredini puta između državne crkve i stroge odvojenosti ${ }^{43}$, njen sistem finansiranja je nadaleko poznat sistem „verskog poreza“, a crkva ima velika ovlašćenja u oblasti radnog prava kada se pojavljuje kao poslodavac, a tada čak istupa samostalno, kreirajući društvenu delatnost u koju je uključena. ${ }^{44}$ Svoje mesto u središtu raskrsnice između dva modela Nemačka je zaslužila proklamovanom aksiološkom neutralnošću države, kojom se sprečava povlašćen položaj neke verske zajednice, ali ujedno i omogućava da bilo koja verska zajednica ne bude nepovoljnije tretirana od bilo kojeg drugog ideološkog uverenja. S druge strane, kooperativni segment nemačkog modela jača to što religija nije potpuno izgnana iz društvenog života, te je dozvoljeno javno izražavanje verskih ubeđenja, ali samo pod uslovom da je ono sastavni deo postojećeg društvenog stava i da se zasniva na dobrovoljnosti svih učesnika ${ }^{45}$. $\mathrm{Na}$ taj način država je sprečena da se poistoveti sa bilo kojom verskom doktrinom, ali je, jednako efikasno, sprečeno nametanje ateizma kao dominantnog $\mathrm{u}$ javnom diskursu.

Uređenje odnosa države i crkve u Italiji ima trojaku specifičnost. Najpre, posebnost se ogleda u tome što se sedište poglavara Katoličke crkve nalazi u gradu Rimu, što implicira značajan uticaj katoličanstva na italijansko društvo, i istorijsko nasleđe, što je Ustavom i priznato, uz razdvajanje organizacija države i crkve koje su svaka u svom delu suverene. Druga osobenost jeste stepenast model priznate crkve - u Italiji se odnos prema verskim zajednicama, prema stepenu uređenosti aktima, svodi na tri nivoa - prvi nivo je uređenost odnosa između države i većinske katoličke religije, drugi nivo su potpisani sporazumi s drugim denominacijama i treći, najniži stepen, čine denominacije koje ne uživaju državnu zaštitu i, za razliku od prve dve, ne mogu biti partneri Ministarstva prosvete $\mathrm{u}$ organizovanju verske nastave. Takav

43 G. Robers, „Church Autonomy in the European Court of Human Rights Recent German Cases“, Pravo, vera i kultura (ur. Raković, Đurić), Beograd 2012, 55.

44 Božić, 52.

45 Ibid., 50. 
tretman, prema kojem su neke od crkava i verskih zajednica ,jednakije“ od drugih, izaziva u praksi još veće kritike i probleme, ako se zna da su na dnu ove trostepene piramide italijanski muslimani i Jehovini svedoci, grupe koje su po brojnosti odmah iza katoličke zajednice. Treća osobenost italijanskog modela je - sve uočljiviji u poslednjim decenijama - talas sekularizacije kao ideologije, što kao posledicu ima izmenu tradicionalnih rešenja u osetljivim pitanjima, poput razvoda, abortusa, dekriminalizacije eutanazije, blasfemije itd. I najzad, treći indikativni primer u sistemu priznatih crkava koji želimo da istaknemo jeste primer Holandije. Njena početna pozicija, na ovoj skali različitih modaliteta uređenja crkvenodržavnih odnosa, jeste na koordinatama ostalih država, sa sistemom priznatih crkava liberalnodemokratske tradicije. Ali, Holandija je, posebno od osamdesetih godina prošlog veka, nizom ustavnih finansijskih i upravnih odredaba krenula putem potpune separacije crkve i države, što će reći ka krajnjem polu naše skale. U Ustavu Holandije se ne spominju crkve ni u kom kontekstu i država se potpuno izuzima iz unutarcrkvenih pitanja, a državni organi, pre svega sudovi, ukidaju široku građanskopravnu autonomiju verskih zajednica, opredeljujući se za put ka potpunoj sekularizaciji. Brojni drugi parametri takođe pokazuju da, iako načelno pripada sistemu priznatih crkava, Holandija postaje sve više prosekularna država, što je još jedan (doduše u obrnutom smeru) argument u prilog tezi o široko postavljenom krugu rešenja statusa crkava i verskih zajednica i njihovog odnosa sa državom.

Svrha navođenja svih pobrojanih uporednopravnih rešenja bila je da se ukaže na to koliko je u većinski liberalnodemokratskoj Evropi danas pogrešno govoriti i odnos države prema crkvi posmatrati isključivo u binarnim obrascima - konfesionalne države ili državne vere i potpuno odvojene crkve od države (sistem rastave i preplitanja kod Marinkovića). Aktuelno stanje je mnogo više iznijansirano i zaslužuje mnogo više pažnje od kategoričkog svrstavanja u jednu od dve, podsećamo, prevaziđene kategorije. To bi bilo korisno usvojiti i kada govorimo o našem ustavnom rešenju i nedoumicama koje su iskrsavale $u$ njegovom tumačenju. ${ }^{46}$

46 Rešenje koje je usvojio naš Ustav, navodeći Srbiju kao sekularnu državu, doneo je više nejasnoća nego jasnog određenja, pre svega zbog toga što se, kao što vidimo, termin sekularno može tumačiti i sprovesti u delo u mnogo raznih varijacija i pokreće brojna pitanja (Trigg, 282). I zato, strogo formalno govoreći, naš ustavni termin ni na koji način bliže ne implicira kakvi odnosi između države i crkve treba da 
Sekularnost kao ideja razdvajanja religije od države, a potom i od društva, nije svuda dostigla jednake domete i nema svugda jednako značenje. Kako to pravilno primećuje Rene Remon u svojoj knjizi o sekularizaciji u 19. i 20. veku, u odnosima religije i društva nema formule koja bi bila bolja od svake druge, a potvrdu ovih reči dobili smo upravo analizirajući pojedinačna rešenja više evropskih država.

\subsection{Tokovi sekularnosti}

Ipak, u obilju tih „formula“ i u procesu sekularizacije, kao jednom istorijskom procesu, ipak možemo nazreti određene pravilnosti koje se pokazuju kao opšte i zajedničke, do ove tačke u današnjici kada valja postaviti pitanje perspektive ideje sekularnosti. Rene Remon ( $R$. Rémond) deli proces sekularizacije na etape, zavisno od promena i pukotina koje je svaka od tih etapa nanela jedinstvenoj vezi crkve i države, koja je bila početna tačka, naglašavajući izrazito nepravolinijski razvoj tog procesa. Prva etapa je bilo priznavanje jednakosti svačijeg prava na slobodu savesti i veroispovesti i ukidanje svih oblika nejednakosti zasnovane na njoj. Ukidanje diskriminacije verskih manjina je negde išlo postepeno, kao u Engleskoj, a negde naprečac, kao u revolucionarnoj Francuskoj, no rezultat je bio isti - konfesionalni karakter države je ostao, ali se verski pluralitet morao uvažiti. U sledećoj fazi, emancipacijom verskih manjina nužno su smanjene nadležnosti $\mathrm{crkve}^{47}$, što se najjasnije odrazilo na upravne i administrativne radnje koje su se preklapale s crkvenim interesom uređenja životnih situacija (rođenje, sklapanje braka, sahrane i sl.). Francuska je prednjačila u ekstremnim rešenjima, te je već 1792. godine uvela građanske matične knjige i ubrzo potom nastavila da uklanja religijsku konotaciju u ostalim administrativnim i javnim evidencijama. $U$ toj fazi su se otvorila sporna pitanja, poput regulacije braka, obreda pogreba i drugih, koje će i u kasnijim fazama opterećivati odnose države i crkve. Iz te tačke, proces odvajanja države i religije krenuo je u ona dva smera po

budu, osim što ostaje podesno sredstvo kojim će svako čija ideološka obojenost nađe za shodno da pokuša da crkvu i javno ispoljavanje verskih ubeđenja potpuno izbaci iz društvenog života. Kritičari, i oni koji to drugačije tumače, navode da je iz Ustava izbačena odredba o mogućnosti finansijske podrške crkvama i verskim zajednicama, što je, kako tvrde, dokaz pravca striktne odvojenosti ka kojoj je naš Ustav krenuo, iako priznaju da se tom ustavnom odredbom ne zabranjuje izričito da se taj tip sekularnosti shvati u kooperativnom vidu.

47 R. Remon, Religija i društvo u Evropi, Novi Sad 2017, 164. 
kojima ovo poglavlje i nosi naziv. Jedan izbor je bio laicitet - ta svojevrsna antireligija, čija je težnja da zameni postojeću religiju izrazito antiverskim karakterom. ${ }^{48} \mathrm{Njen}$ nastavljač, s potpuno identičnim motivima, bio je agresivni sekularizam, koji postoji i danas i koji ima i elemente komunističke ideologije, o čemu će još biti reči. Drugi izbor je bila sekularnost zasnovana na liberalnim idejama, koja je prevladala u protestantskom svetu i koja je po pravilu vodila sistemu priznatih crkava. S tačke gledišta agresivnog laiciteta (što se može shvatiti i kao pleonazam), početkom 20. veka (posebno nakon 1905. godine), činilo se da sve ide prema neizbežnom i trajnom raskidu religije i države, međutim, danas smo svedoci da tok evolucije nije uvek pratio krivu (sekularizacija) za koju se činilo da se lagano iscrtava i da nastavlja da raste kako su neki predviđali. ${ }^{49}$ Evolucija odnosa je, dakle, daleko od konačne tačke, pa iako povratak na početak, tačnije povratak na konfesionalnu državu nije moguć jer je neutralna država mesto opšteg konsenzusa širom evropskog kontinenta i, kao takva, ona je uzdignula na rang načela kakvo je, na primer, podela vlasti, čini se da su u procesu sekularizacije na putu odvajanja crkve i države učinjeni koraci unazad, čak i u samoj Francuskoj, kao pioniru konfliktnog laiciteta. ${ }^{50}$

Taj korak unazad već ima svoje posledice u razrešenju nečega što je decenijama predstavljalo glavni kamen spoticanja, tzv. školsko pitanje, koje je bilo predmet sporenja čak i u vreme verske države, dakle i pre prvih naznaka separacije. ${ }^{51} \mathrm{Na}$ tom pitanju, onako kako je ono rešeno širom evropskog kontinenta danas a i kako je u nekoliko presuda (najpoznatiji slučaj Lauci) Sud u Strazburu tumačio EKLJP, može se graditi tok procesa sekularnosti u budućnosti. Nagib te krive uopšte više ne mora biti tako oštar, budući da sekularna država kao opšteprihvaćeno načelo predstavlja ,jemstvo individualne slobode i jednakosti građana, ali njena priroda nije antiklerikalna“. ${ }^{52}$ „U razdvajanju svetog

48 Ibid., 173.

49 Ibid., 188.

50 Treba spomenuti i segment koji se prečesto previđa jer predstavlja „naličje“ procesa sekularizacije. Taj segment su koristi koje crkva dobija od sekularizacije jer kako se sada država polako izvlači iz tog zagrljaja i ostaje bez religijske potpore, tako i crkva, s druge strane, dobija slobodu, nesputana kontrolom države u organizovanju i delanju. Zbog tvrdog i antisekularnog stava koji su crkve prirodno prvobitno zauzele, aspekt „obrnute sekularizacije“ se često izgubi iz vida. Taj aspekt desekularizacije crkava može blagotvorno i ključno uticati na hrišćansku crkvu i njen izvorni karakter koji je počela da gubi još za vreme „simfonije“ i vlasti vizantijskog cara Teodosija.

51 Remon, 178.

52 Istakao autor. 
i svetovnog ona ne nalazi metod konačnog obračuna, već načelo mirne koegzistencije. ${ }^{53}$ Primer verske nastave, ali i ostale potvrde ideje koju zastupamo govore u prilog tome da više nije reč samo o mirnoj koegzistenciji već se otišlo i dalje, ka upućenosti na saradnju. Ta saradnja se uvek „ostvaruje nauštrb aktuelne sekularizacije (kao ideološke predstavke) globalnog društva, ali saradnja ne znači i izneverivanje osnovnih načela sekularizacije, koja ostaje nepovređena u situacijama u kojim se nadležnost odgovrnosti i interesi crkve i države preklapaju“, kako to primećuje Rodni Stark (R. Stark).

U Evropi je taj princip shvaćen i primenjen. Sticajem okolnosti, u našem društvu to nažalost nije bio slučaj. Neretki su zahtevi raznih činilaca javnog i društvenog života da u ime evropskih vrednosti i načela sekularizma (ne sekularnosti) crkvama i verskim zajednicama bude onemogućeno oglašavanje o bilo kom pitanju iz javne sfere ${ }^{54}$, pa čak i zabranjeno učešće u javnom životu na bilo koji, pa i simbolički način. Ti zahtevi, počevši od pomenutog tumačenja Ustava iz 2006. godine, samo govore o tome koliko se ideal sekularne države kod nas pogrešno shvata i koliko su zahtevi za njegovim sprovođenjem izvitopereni, a ponekad i zloupotrebljeni od agresivnog sekularizma. Već smo spomenuli da treba praviti terminološku razliku pojmova sekularnosti, kao ideje uređenja odnosa države i crkve, i sekularizma, kao savremene ideologije čiji je osnov borba protiv religije, pa i ustoličenje umesto religije, koja treba da ostane „u tragovima“. Zbog toga se može desiti da se kolege koje se zalažu za sekularnost u našem društvu i, recimo, u nemačkom, apsolutno ne razumeju, budući da pod tim pojmom podrazumevaju potpuno različite stvari. $S$ druge strane, mnogo je verovatnije da će pojmovi biti podudarni i da će razumevanje biti mnogo veće između našeg i drugih društava postkomunističke Istočne Evrope. Zašto? Zato što i naše i ostala društva Istočne Evrope pripadaju nasleđu komunističkog narativa o odnosu države i crkve. Taj narativ karakteriše, za sadašnja pravna i civilizacijska dostignuća, neshvatljiv i neprihvatljiv akt negiranja verskih sloboda, proganjanja crkve i ustoličenja marksizma za zvaničnu dogmu (novu religiju). ${ }^{55}$ Svaka podudarnost sa ideologijom agresivnog i konfliktnog sekularizma nažalost nije slučajna, budući da shvatanje sekularnosti onako kako se u našem

53 Božić, 92.

54 Krstić, 126.

55 T. Marinković, „Prilog za javnu raspravu o ustavnosti ZCVZ“, Anali Pravnog fakulteta u Beogradu 1/2011, 377. 
društvu danas razume, direktno izvire iz tog komunističkog modaliteta „odnosa“ crkve i države. ${ }^{56}$ Čak i zagovornici veće i doslednije sekularizacije srpskog društva, ako su ozbiljni u naučnim analizama, takav sistem moraju da „ostave po strani“. Smatrali smo da je ova digresija na nesporazum koji vlada u našem društvenom životu neophodna da bismo ukazali na to gde se mi nalazimo u odnosu na dostignuća evropskih vrednosti u predmetu sekularne države. U toj oblasti nemerljivu ulogu odigrale su Evropska konvencija sa svojim članom 9 i presude koje su tu odredbu dodatno rastumačile. Upravo su neka od tih tumačenja potvrdila potrebu za načelom saradnje kao jednom od vrednosti evropskog društva, kojima, nominalno, i naše društvo teži.

\section{REŠENJE EVROPSKE KONVENCIJE O LJUDSKIM PRAVIMA I PRIKAZ POJEDINIH ODLUKA SUDSKE PRAKSE}

Svako ima pravo na slobodu misli, savesti i veroispovesti; ovo pravo uključuje slobodu promene vere ili uverenja i slobodu svakog da, bilo sam ili zajedno sa drugima, javno ili privatno, ispoljava veru ili uverenje molitvom, podučavanjem, običajima i obredom.

Sloboda ispovedanja vere ili ubeđenja sme biti podvrgnuta samo onim ograničenjima koja su propisana zakonom i neophodna u demokratskom društvu u interesu javne bezbednosti, radi zaštite javnog reda, zdravlja ili morala ili radi zaštite prava i sloboda drugih (čl. 9 EKLJP). ${ }^{57}$

Nakon svega do sada izloženog, valjalo bi videti kakav status sloboda veroispovesti ima u najširem od tri sistema zaštite na našem kontinentu, koji je ustanovljen usvajanjem EKLJP 1950. godine. Sloboda veroispovesti je uvrštena u član 9 EKLjP, zajedno sa slobodom misli i savesti, što pokazuje širi okvir određenja ${ }^{58}$, jer su istovremeno

56 Uzimajući u obzir da predlog anti (grč. ả vii) u grčkom jeziku ima značenje i protiv i umesto, zanimljivo je istaći korelaciju koju jakobinska i komunistička „antireligija“ imaju sa opravdanjem Berđajevljevog određenja čoveka kao nužnog homo religiosus-a, kao i s citatima Voltera s početka rada.

57 Dž. Murdok, Sloboda misli, savesti i veroispovesti - vodič za primenu člana 9 EKLJP, Savet Evrope, Beograd 2008, 14.

58 Božić, 18. 
u članovima 10 i 11 uređene slobode izražavanja i okupljanja, koje se sistemskim i suštinskim tumačenjem mogu, a često se i dovode u vezu sa pravima iz člana 9 , posebno u slučajevima kada omogućavaju da se na efikasniji način ostvari zaštita povređenog prava. ${ }^{59}$

Takođe, kao jedno od suštinskih prava zajemčenih EKLJP, i sloboda veroispovesti iz člana 9 može biti osnov za pozivanje na temeljno načelo zabrane diskriminacije iz člana 14 , što može dati nov kvalitet predstavkama koje se pojavljuju pred Sudom u vezi sa članom 9, a koje se ne smatraju kršenjem prava ako se ne dovedu u vezu sa načelom iz člana 14 Konvencije. Najzad, u EKLJP se jemči još jedna srodna garancija, koja zaokružuje skelet slobode veroispovesti je člana 2 Prvog protokola uz EKLJP, koji se bavi odnosom verskog uverenja roditelja i obrazovanja. U pomenutom članu se predviđa da, u okviru opšteg prava na obrazovanje, država „poštuje pravo roditelja da obezbede obrazovanje deteta i nastavu u skladu s svojim verskim i filozofskim ubeđenjima“. ${ }^{60}$ Jurispudencija Evropskog suda za ljudska prava u vezi sa tim članom suštinski je razdvojila integritet nastave i objektivno i kritičko sprovođenje obrazovnog programa, $s$ jedne strane, od nedozvoljene indoktrinacije, $s$ druge strane, „poštujući pluralizam i toleranciju u javnom obrazovanju“" ${ }^{1}$

Sadržina samog prava iz člana 9 EKLJP je dualnog karaktera: ona ima tzv. forum internum, kao pravo na imanje i menjanje uverenja koje se ispoljava u izvesnoj manifestaciji, ali je izričito naglašeno da se ispoljavanje ne odnosi na svaki čin koji je motivisan verom ili je nastao pod njenim uticajem. ${ }^{62} \mathrm{U}$ početku svoje jurispudencije Sud je forum-u internum-u davao prevagu nad drugim aspektom, koji se naziva forum externum i podrazumeva kolektivni segment člana 9 koji se odnosi na ispoljavanje i uživanje vere u zajednici sa drugim. Taj aspekt prava iz člana 9 obuhvata i postojanje verske organizacije i njihovo autonomno delovanje, kao što je navedeno u presudama koje se tiču državne intervencije u unutrašnju organizaciju i osnivanje verskih zajednica (Besarabijska mitropolija protiv Moldavije i drugi slični slučajevi).

Još jedan aspekt prava iz člana 9 EKLJP sadržan je u drugom stavu, kojim su predviđeni slučajevi u kojima je moguće ograničenje

59 Murphy v. Ireland, Otto-Preminger-Institut v. Austria i slične presude.

60 Murdok, 88.

61 Predstavke br. 10228/82 i 10229/82, W. and D., M and M., H. I. v. The UK i drugi.

62 Murdok, 28. 
slobode veroispovesti. I formalno i jezički taj stav ni po čemu ne odstupa od načina na koji se propisuju ograničenja i u drugim članovima EKLJP, a to je da je takvo ograničenje moguće samo „ako je propisano zakonom, neophodno u demokratskom društvu u interesu javne bezbednosti, zaštite javnog reda, zdravlja, morala i prava drugih". Svaki od tih aspekata biće razrađen posebno jer je u sudskoj praksi bliže određeno značenje svakog od tih pravnih standarda. Drugim stavom člana 9 Sud je usmeren da odredi da izvesno „mešanje“ države u prava iz tog člana ne predstavlja njegovo kršenje ako takvo mešanje ispuni navedene uslove i po tome član 9 nije izuzetak. Međutim, postoji jedna osobina koja je svojstvena za jurisprudenciju Suda isključivo po tom članu, a to je karakter prava koje on garantuje, zbog kojeg Sud nije uspeo da stvori jedinstvenu i ujednačenu praksu postupajući po brojnim i raznovrsnim predstavkama koje su stigle u Strazbur. Kao što smo u prethodnim poglavljima verno prikazali, Evropu karakteriše pluralitet modela odnosa crkve i države, uzrokovan složenim istorijsko-sociološkim procesima ${ }^{63}$ i upravo je to suštinska teškoća sa kojima se Sud susreće u nastojanjima da iskristališe jedinstven stav o legitimnosti ili nelegitimnosti „mešanja“ države u prava pojedinaca iz člana 9. Prihvatajući tu svoju svojevrsnu hendikepiranost, u slučaju Marfi protiv Irske Sud je konstatovao da, kao jedan međunarodni forum, nije dovoljno dobro pozicioniran u poređenju sa državnim vlastima za rešavanje spornog pitanja. ${ }^{64}$ Identičnu argumentaciju kao u slučaju Lejla Sahin protiv Turske Sud je iskoristio i u slučaju Institut Oto Preminger protiv Austrije i u drugim slučajevima koji su se zasnivali na trendu pridavanja velikog značaja ulozi nacionalnih organa i opravdanosti njihovih mera. Drugi trend u jurispudenciji nazreo se još među prvim presudama, kao što je Kokinakis protiv Grčke, u kojoj Sud takođe pluralizmu daje centralno mesto, ali i pokazuje „pojačanu želju da se izdigne iznad konstatacije diverziteta posebnih slučajeva i država i artikuliše neke generalne principe koji

63 Iako je tačno da Evropski sud u svojim presudama nije definisao sekularnost, čak je nije pominjao izuzev u nekoliko slučajeva (najznačajniji je primer $L$. Sahin protiv Turske), upravo u tome je veza između svega prethodno izloženog i ovog poglavlja. U pomenutom slučaju i načela rodne ravnopravnosti odigrala su izvesnu ulogu, ali, bez obzira za to, Sud je proklamovao „da se kod pitanja odnosa između države i veroispovesti poseban značaj treba pridati ulozi naconalnih organa... budući da u Evropi nije mogućno uočiti jednoobrazni koncept značaja religije u društvu“ (ibid., 66).

64 Ibid., 59 
bi važili za sve potpisnice Evropske konvencije“ ${ }^{65}$ Kao plod takvih nastojanja iskristalisalo se nekoliko principa.

1. Princip autonomije religijskih zajednica koji pretpostavlja obavezu države da se ne meša u unutrašnje poslove religijske zajednice, da ne utiče i ne potpiruje razmirice koje eventualno postoje i da ne isključuje svaku već samo proizvoljnu intervenciju budući da je intervencija koja je u skladu s neophodnošću u demokratskom društvu opravdana. ${ }^{66}$ Ovo stoga što, kako se navodi u presudi Vrhovni savet Islamske zajednice protiv Bugarske, „autonomno postojanje verskih zajednica čini neraskidivi deo pluralizma u demokratskom društvu“.67 Princip autonomije religijskih zajednica bio je osnov na kojem je Sud temeljio svoje mišljenje u ovom ali i u brojnim drugim slučajevima: Šerif protiv Grčke (1999), Aga protiv Grčke (2002), Hasan i Čauš protiv Bugarske (2000), Besarabijska mitropolija protiv Moldavije (2001). Za sve te slučajeve Sud je utvrdio da garancija slobode veroispovesti podrazumeva mogućnost da zajednica funkcioniše mirno, slobodna od arbitrerne državne intervencije. ${ }^{68}$ Pojam funkcionisanja detaljnije je određen $\mathrm{u}$ presudi Svetomihajlovska parafija protiv Ukrajine (2007) i podrazumeva aktivnosti kao što su biranje lidera, stvaranje sopstvenih ustanova, ustanovljenje teološke doktrine, procedure primanja novih i ekskomuniciranja vernika koji su već članovi zajednice. ${ }^{69}$

2. Princip neutralnosti države je sledeći i najvažniji princip koji je sudska praksa iznedrila. On je neraskidivo povezan sa prethodnim i čini njegovo naličje, te se prvi princip ne može izdvojeno sagledavati od drugog, a taj drugi nalaže da u obavljanju svojih dužosti i odnosu s religijskim zajednicama država mora ostati neutralna i nepristrasna. Ako pođemo od činjenice da je država neprikosnoveni garant pluralizma koji je proklamovan kao jedna od vrhunskih evropskih vrednosti, kako je navede-

65 J. Ringelheim, „Rights, Religion and the Public Sphere: ECHR in search of a Theory?", A European Dilemma: Religion and the Public Sphere (eds. C. Ungureanu,

L. Zucca), Cambridge University Press, Cambridge 2012, 283-304.

66 Murdok, 76.

67 Ibid.

68 Ringelheim, 287.

69 Ibid. 
no u presudi Išik protiv Turske, u svetlu tog principa može biti kontroverzno pitanje da li je koncept državne crkve kao jedan od izraza tog pluralizma modaliteta odnosa države i crkve u skladu s principom neutralnosti. To je izuzetno važno pitanje budući da odgovor na njega, kao što smo i u ranijim poglavljima naglasili, može ukazati na to šta se pod sekularnošću zaista podrazumeva, a šta je njegova izvrnuta slika. Sud stoji na stanovištu da koncept državne religije ili crkve nije sam po sebi u suprotnosti s načelima člana 9 , dok god se poštuju prava svih pojedinaca pripadnika te crkve, ali i drugih zajednica. U presudama Hanijske katoličke crkve protiv Grčke (1997) i Batista el Salvador s Moratilom protiv Španije (1992, D.R. 72) Sud je otišao još dalje, navodeći da javne vlasti nisu dužne da obezbede identičan pravni status svim religijskim zajednicama već mogu institucionalizovati način saradnje sa svakom od njih. ${ }^{70}$ Ako se setimo skale na kojoj je predstavljen celokupan diverzitet odnosa crkve i države u Evropi, te sudske presude direktno pokazuju da jedna tačka na toj skali, koncept kooperativne odvojenosti, nije u suprotnosti sa načelom neutralnosti i samim tim sa pravom garantovanim članom 9 EKLJP.

U vezi sa tim principom, Sud je dvostepeno razmatrao još jedan slučaj koji je zbog rasprave koju je u evropskoj javnosti prouzrokovao postao toliko navođen da se bez njega ne može zamisliti bilo kakvo razmatranje o temi o kojoj pišemo. Reč je o raspravi o opravdanosti postojanja Raspeća u italijanskim javnim školama, koja je vrhunac doživela u suđenju u Malom, pa Velikom veću u slučaju Lauci protiv Italije (2011). Taj slučaj je izazvao veoma žustre polemike u svim sferama javnog života širom Evrope jer se na njemu prelamalo jedno šire pitanje, pitanje opšte opravdanosti mesta religije (ne samo hrišćanske) u javnom diskursu evropskih društava. U postupanju po predstavci Malo veće je smatralo da je princip neutralnosti nespojiv sa poistovećivanjem $s$ bilo kojom religijom i njenim simbolima. Takođe, navedeno je i da prisustvo Raspeća, kao vrsta psihološkog pritiska, može latentno uticati na decu čiji roditelji nisu hrišćani, što nije u skladu s Dodatnim protokolom i njegovim članom 2. Tada se otvorilo i pitanje da li treba sačuvati religijski identitet evropskih naroda

70 Ibid., 289. 
i kulture onako kako je on ugrađen u njihovu istoriju. ${ }^{71}$ Uviđajući opasan potencijal mogućeg presedana koji bi mogao otići čak do potezanja pitanja opravdanosti „skandinavskog krsta“ na zastavama pojedinih zemalja (?! ${ }^{72}$, Veliko veće je skoro jednoglasno preinačilo presudu obrazlažući svoju odluku time da Malo veće nije samo želelo da podstakne pluralizam (u čemu zapravo i nema ničeg suštinski pogrešnog), već i da istakne poseban svetonazor, tzv. vrednosti sekularne države, uzimajući bezrezervno princip da je neutralnost izraz i nužna posledica sekularnosti. ${ }^{73} \mathrm{Na}$ tom konkretnom primeru vidimo opravdanost onoga što smo u ranijim poglavljima navodili i važnost određenja sekularnosti za dalju sudsku praksu Evropskog suda, budući da su nam jasne posledice do kojih može doći, kao u primeru odluke Malog veća, ako se princip neutralnosti postavi na klimave i u suštini antidemokratske temelje agresivnog sekularizma. Ovakvo, možda čak i oštrije stanovište izneo je u svom izdvojenom mišljenju sudija Bonelo navodeći da „Konvencija ovlašćuje Sud da štiti slobodu savesti i veroispovesti, ali ne i da primorava države na sekularizam niti ih uteruje u šeme neutralnosti zasnovane na sekularizmu... budući da je zadatak Konvencije da štiti slobodu veroispovesti kao osnovno ljudsko pravo, ali ne i vrednosti koje nisu štićene Konvencijom kao što je sekularizam ili odvojenost Crkve i države “" ${ }^{74}$ Sudija Bonelo zna da se u EKLJP ne reguliše niti se navodi sekularnost, ali isto tako zna i da se sekularnost mora tumačiti na ispravan nediskriminatorski način jer će se, u protivnom, sloboda veroispovesti tumačiti na načelima sekularizma, koja, izlišno je iznova naglašavati, imaju izrazit antireligijski ton. Pitanje koje se sa pravom može u tom slučaju postaviti nije da li bez sekularizma ima neutralnosti već da li je sekularizam kršenje, pa čak i negacija principa neutralnosti. ${ }^{75} \mathrm{U}$ odgovoru na to pitanje, svaka država, $u$ skladu s pluralizmom, ali i Evropski sud, moraju se opredeliti da li žele slobodu $z a$ religiju ili slobodu od religije.

71 Trigg, 277.

72 Ibid., 278.

73 Ibid.

74 Case of Lautsi and Others v. Italy, https://hudoc.echr.coe.int/eng\#\{\%22fullt ext\%22:[\%22lautsi\%22],\%22documentcollectionid2\%22:[\%22GRANDCHAMBER\%22 ,\%22CHAMBER\%22],\%22itemid\%22:[\%22001-104040\%22]\}, 11. mart 2020.

75 Trigg, 278. 
3. Princip sekularnosti osnova pravnog sistema. I taj princip na određeni način derivira iz prethodnog, principa neutralnosti i Sud je, vodeći se njime u dva slučaja, ustanovio da se pravni sistem ne može zasnivati na islamskom pravu, šerijatu (slučaj Refah partije protiv Turske), niti na poštovanju hrišćanstva kao osnova političkog sistema države priznavanjem njegovog autoriteta u obaveznoj zakletvi na Jevanđelju (slučaj Buskarini protiv San Marina). Takva praksa, kao što smo videli na nekim drugim mestima, ne utiče na kršenje načela sekularnosti jer se ne sme povući znak jednakosti između jednakog postupanja i upadanja u relativizam koji insistira na tome da država mora biti imuna na sva religiozna verovanja ${ }^{76} \mathrm{U}$ svetlu toga, taj princip treba tumačiti usko, kao konkretizaciju civilizacijskog dostignuća odvojenosti religijskog od državnog aparata i kao još jednu potvrdu da sistem kakav je teokratija nije u saglasnosti sa onim što je propisano Konvencijom.

Kao što smo već naveli, sloboda savesti i veroispovesti nije apsolutna već podleže određenim ograničenjima - državi je dozvoljeno da se umeša, ali ne i da krši slobodu veroispovesti ${ }^{77}$, samo onda kada to mešanje prođe višedelni kvalitativni test: da je u skladu sa zakonom, da je neophodno u demokratskom društvu i da služi nekom od legitimnih interesa pobrojanih u članu 9, stav 2.

Kada je reč o prvom uslovu, predvidenosti u zakonu, Sud je u razradi tog standarda, u presudi u slučaju Sunday Times protiv Ujedinjenog Kraljevstva (1979), istakao dva kriterijuma pomoću kojih se bliže određuje da li je mešanje države bilo ili nije bilo predviđeno u zakonu. Prvi kriterijum je dostupnost zakona građanima, a drugi preciznost norme koja pretenduje da se podvede pod zakon u smislu tog člana, kako bi građani adekvatno mogli da urede i svoje ponašanje i da predvide posledice odstupanja od njega. ${ }^{78}$ Sud može mogućnost adekvatnog upoznavanja sa normom i predviđanja posledica određivati pomoću brojnih drugih merila, kao što je, na primer, poznata nacionalna sudska praksa, a ne samo jasnoća zakonske odredbe, te je u tom smislu sudijama ostavljen određen slobodan prostor da ta merila vagaju od slučaja do slučaja.

\footnotetext{
76 Ibid., 285.

77 Murdok, 36.

78 Ibid., 51.
} 
Znatno važniji i kompleksniji je sledeći uslov: da mešanje države, to jest ograničenje prava iz člana 9, bude neophodno u demokratskom društvu. Da bi država koja opravdava svoje mešanje zadovoljila taj test, mora da dokaže da intenzitet tog mešanja, koje je osnov spora, odgovara akutnoj društvenoj potrebi, da je srazmerno legitimnom cilju kojem se teži i da je opravdano relevantnim razlozima ${ }^{79}$ a Sud je po ovom pitanju konkretizovao i izdvojio neke od vrednosti kao temeljne za evropske demokratije. Među njima centralno mesto zauzima pluralizam. Pluralizam je postavljen na pijedestal vrhunske vrednosti čijoj zaštiti služi član 9 i koji se mora braniti i podsticati čak i u slučajevima kada je na jednom širem planu javnog reda on uzrok sporne situacije. ${ }^{80}$ Takvo rešenje inspirisano je onim volterovskim duhom koji, iako sa njim nije saglasan, do smrti brani pravo da se drugačije mišljenje čuje.

Jedan aspekt na taj način shvaćenog pluralizma je i neminovna supsidijarnost uloge Suda u odnosu na snagu koju nose nacionalne vlasti i vrlo široko omogućena primena polja slobodne procene (margin of appreciation) u svetlu u kojem se uvek cene neophodnost neke mere i njena usklađenost sa demokratskim društvom. Da to polje slobodne procene, neophodno u sistemu zasnovanom na pluralizmu, ne bi potpuno odrešilo ruke potpisnicama Konvencije i istovremeno ne bi poslužilo kao pilatovski izgovor Sudu, u presudi Hendisajd protiv Ujedinjenog Kraljevstva (1976) izričito je naglašeno da polje slobodne procene „ne znači neograničenu moć države, već da je i ona podložna evropskom nadzoru u okviru kog Sud ipak ima poslednju reč da li je neko ograničenje u skladu s Konvencijom". 81

\section{ZAKLJUČAK}

Na samom početku ovog rada naveli smo koliko su u zabludi bili pojedini mislioci koji su pre vremena sahranili religiju sa svim onim što ona sobom nosi. Pojedini glasovi iz suprotnog tabora na to su odgovorili da je proces sekularizacije dospeo u ćorsokak i da sekularizacija društva nije ni moguća u krajnjem slučaju. Smatramo da i oni greše jednako kao i ovi prvi. Argumente za takav stav koji je osnovna teza ovog rada ponovili smo više puta i proželi kroz svako poglavlje da ih

$\begin{array}{ll}79 & \text { Ibid., } 53 . \\ 80 & \text { Ibid., } 56 . \\ 81 & \text { Ibid., } 57 .\end{array}$ 
je izlišno ponovo navoditi i u zaključnim razmatranjima. Dovoljno je reći da su prvi precenili sekularizovan svetonazor a drugi ga potcenili. Istina je da je proces sekularizacije prohujao evropskim kontinentom i zdušno doprineo da lađa evropskog društva i kulture uplovi u neke mirnije vode, vode postsekularne ere. U toj eri sekularizam kao ideologija nema šta da traži, ali sekularnost kao načelo, kao dodirna tačka slobode $i$ jednakosti, kako navodi Murdok, s pravom zauzima centralno mesto. Evropski sud za ljudska prava, kao svojevrsni krmaroš kroz ponekad mutne i neodređene virove, treba da ostane na postsekularnom kursu, koji se civilizacijski pokazao kao nadmoćan u odnosu na dva konfrontirana i prevaziđena gledanja. Stoga zaista ohrabruje to što u jednoj presudi, koju pravna teorija smatra jednom od prekretnica u odlučivanju Suda o pitanjima iz člana 9 EKLJP, presudi u slučaju Kokinakis protiv Grčke (1993), Sud definiše slobodu misli, savesti i veroispovesti kao ,jedan od temelja 'demokratskog društva'... i da od sprovođenja člana 9 zavisi pluralizam koji je u demokratskom društvu neotuđiv i teško izvojevan tokom niza vekova“. 82

\section{LITERATURA}

Fidas, Vlasije, Kanoni i dijalog, Otačnik, Beograd 2018.

Robers, Gerhard, Država i crkva u Evropskoj uniji, Pravoslavni bogoslovski fakultet, Beograd 2012.

Perić, Dimšo, Crkveno pravo, Beograd 2006.

Mitrović, Dragan, „Troicki o crkvenom pravu i njegovom odnosu s državnim pravom“, Pravo, vera i kultura, Beograd 2012.

Krstić, Zoran, Hrišćanstvo u vrtlozima savremenosti, Kragujevac - Požarevac 2016.

Krstić, Ivana, Paunović, Milan, Krivokapić, Boris, Međunarodna ljudska prava, Beograd 2016.

Alfejev, Ilarion, „Hrišćanstvo pred izazovima militantnog sekularizma“, https:// teologija.net/hriscanstvo-pred-izazovom-militantnog-sekularizma/.

Božić, Marko, Laička država kao jemstvo slobode savesti $i$ veroispovesti, Beograd 2010.

Dincelbaher, Peter, Istorija evropskog mentaliteta, CID, Podgorica 2009.

Remon, Rene, Religija i društvo u Evropi - sekularizacija u 19. i 20. veku, Akademska knjiga, Novi Sad 2017.

82 Ibid., 56. 
Avramović, Sima, „Poimanje sekularnosti u Srbiji - refleksije s rasprave u Ustavnom sudu“, Anali Pravnog fakulteta u Beogradu 2/2011.

Marinković, Tanasije, „Prilog za javnu raspravu o ustavnosti ZVCZ“, Anali Pravnog fakulteta u Beogradu 1/2011.

Habermas, Jirgen, Jozef Racinger, „Dijalektika sekularizacije - iznad uma i religije“, https://pescanik/wp-content/PDF/Habermas_Racinger_debata.pdf.

Lok, Džon, Pismo o toleranciji, Službeni glasnik, Beograd 2015.

Ringelheim, Julie, „Rights, Religion and the Public Sphere: The European Court of Human Rights in Search of a Theory?", A European Dilemma: Religion and the Public Sphere, Cambridge University Press, Cambridge 2012.

Trigg, Roger, „Religion in the Public Forum“, Ecclesiastical Law Society, 2011.

Murdok, Džim, Sloboda misli, savesti $i$ veroispovesti: vodič kroz primenu člana 9 Evropske konvencije o ljudskim pravima, Savet Evrope, Beograd 2008.

Blagojević, Mirko, „Savremena religioznost studenata i desekularizacija srpskog društva“, Postsekularni obrt (ur. M. Blagojević, T. Bajović, J. J. Maksimović), Beograd 2013.

Vasilije Marković

Undergraduate student

Faculty of Law University of Belgrade

\section{FREEDOM OF RELIGION AND THE CONCEPT OF SEPARATION OF CHURCH AND STATE IN EUROPEAN CONVENTION OF HUMAN RIGHTS}

\section{Summary}

This paper was written on the occasion of the V Student Conference in Theory and Philosophy of Law, on the topic International and European Law - Theoretical Problems. The discussion of the significance of the term of secularity is crucial for understanding the relationship between religion and the state authorities, on the one hand, and the individual's freedom of religion, on the other. The ambiance of this relationship is crucial for understanding the entitlement of the rights under Article 9 of the European Convention on Human Rights, and therefore a special emphasis is placed on it, both from the point of historical genesis and from the positive approach. Does secularity mean the complete separation of state and religion, or are there within the same secularity and other modalities, and which are they? Where is in that plurality of moduls in the "postsecular" society, our society and where it should be? 
Apart from presenting all the diversity of European modalities, the author in his work emphasizes that it is necessary to redefine the notion of secularity in our society, since, as it is currently perceived, it is completely wrong. The first part deals with the historical genesis of the processes and ideas of importance for understanding the freedom of religion, the second is devoted to the presentation of different models of Church-state relations, while the third, on examples of the practice of the European Court of Human Rights, confirms the thesis that the nature and quality of the state and church relations are crucial for environment within an individual can fully entitle the right guaranteed by the European Convention and its Article 9.

Key words: Separation of church and state. - Laïcité. - Church-state relations. - European convention. - Cooperative model. 